\title{
8
}

\section{INTERACTIVE LEARNING SPACES}

\section{Insights from two wind power megaprojects}

\author{
Cecilia Gregersen and Birgitte Gregersen
}

\begin{abstract}
Kenya and Ethiopia are frontrunners in the region when it comes to adding wind power to their power generation capacity and there is high interest from project developers. The chapter uses the lens of 'interactive learning spaces' to understand how interactions between different stakeholders in a megaproject can lead to the accumulation of technological and managerial capabilities. The two projects offer interesting and different examples of the types of learning spaces in which the transfer of both formalised and tacit knowledge can occur. The chapter argues that it is important to understand and deliberately create and nurture such interactive learning spaces in order to spur and sustain local skills upgrading and capability-building in connection to large infrastructure projects based on imported key technologies.
\end{abstract}

\section{Introduction}

The Lake Turkana Wind Power (LTWP) project in Kenya and Adama II in Ethiopia are two of Africa's largest wind power plants in terms of megawatt (MW) installed. When fully deployed and running, they will contribute substantially to secure better access to reliable energy to households and businesses in Kenya and Ethiopia using sustainable sources of energy such as wind. However, will the two turnkey projects based on imported key technologies also generate local skills upgrading and local capability-building? This question has its roots in a long tradition of technology transfer and development literature emphasising the potential of a variety of flows of knowledge and technologies following large turnkey projects (Bell 2007, 2012). Often such large infrastructure projects generate several local low-skilled jobs related to the construction phase but very 
few local high-skilled jobs. Management and engineering jobs are often supplied from abroad together with the key technologies. When a turnkey project is delivered and the foreign experts have left the country, the sustaining local capability-building is often very limited as Rennkamp and Boyd (2015) confirmed in their study of technology transfer in relation to wind and solar projects in South Africa. Nevertheless, in this chapter we show that a deliberate creation of interactive learning spaces can be one way to establish, maintain, and further develop local high-skilled jobs in relation to large turnkey infrastructure project even with key technologies imported. ${ }^{1}$

In short, 'interactive learning spaces' are defined as 'situations in which different actors are able to strengthen their capacities to learn while interacting in the search for the solution to a given problem' (Arocena and Sutz, 2000, p. 1). Interactive learning spaces integrate the coexistence of learning capabilities and learning opportunities in a specific context. An interactive learning space is therefore a social space created as an opportunity for knowledge producers and users to build innovation capacity, and to devise solutions to specific social and economic problems through interaction.

Relevant learning processes related with problem solving include the capacity to recognise the useful existing knowledge, to detect the missing knowledge needed, to organise the search process to acquire it, to integrate new knowledge into the previous base and the whole into current practices.

(Arocena and Sutz, 2000, p. 7)

There are clear overlaps to Cohen and Levinthal's absorptive capacity concept defined as 'the ability of a firm to recognize the value of new, external information, assimilate it, and apply it to commercial ends' (Cohen and Levinthal, 1990, p. 128). Learning is cumulative and path-dependent or in other words, absorptive capacity depends on the level of prior related knowledge. Introducing the interactive learning space concept in the current chapter underlines the focus on when and under what institutional settings absorptive capacity may develop and how it can be supported by a deliberate process. The institutional settings within and around the projects, and the ability to shape these to foster capability accumulation, are key in shaping the path from technology adoption to learning and innovation (Lema, Iizuka, and Walz, 2015). Furthermore, the idea of creating deliberate learning spaces within projects relates to the literature which looks at the criticality of inter-project learning and cross-project learning (Davies and Hobday, 2005) and how projects may stimulate learning and function as arenas for learning (Lundin and Midler, 2012).

Creation of interactive learning spaces can emerge and develop as a process where actors identify and solve relevant problems - as a reactive process. Interactive learning spaces can also be created as a deliberate and proactive strategy to build capacities and create learning opportunities (Johnson and Lundvall, 1994; Johnson 
and Andersen, 2012; Petersen et al., 2018). In practice, the two forms can interact and mutate into new mixed forms, for instance if a concrete university-industry collaboration project involving a couple of staff develops into a broader collaboration framework between the university and the external partner for starting more student projects and scholar engagement in the future. In both the LTWP and the Adama II case, we focus on two examples of interactive learning spaces that fall into the category of being created as a proactive strategy to capability-building.

Assuming that learning spaces are embryonic points in the development of innovation systems (Arocena and Sutz, 2000), it is relevant to identify and study them empirically - how they emerge, grow, and disappear. In situations where technologies are imported as turnkey projects including agreements on operation and maintenance, the learning opportunities and capability-building for local companies and organisations may be very limited, if a proactive approach to creating learning opportunities is not applied. Even when a proactive approach is in play it still takes continuous investments in learning and capability-building to maintain and accumulate new knowledge.

Deployment of large wind parks is a complex process involving a very broad range of skills and knowledge types, technologies, people, procedures, and organisational arrangements within the different phases from the planning and project development phase, to the production and construction phase, to the final electricity production and maintenance phase. The two wind power projects (LTWP and Adama II) show variations in their set-up, the partners engaged, and the energy systems in which they are embedded, but using the lens of interactive learning spaces on the two case study projects helps us understand how interactions between different stakeholders can lead to accumulation of technological and managerial capabilities. The distinction between multiple learning spaces in these projects bears a resemblance to the ideas of Davies and Brady (2000) that an organisational learning cycle must be put in place to learn from the multiple sets of capabilities required in complex projects.

The analysis of the two wind power projects draws on data collected during site visits to the Adama II project in November 2017 and the LTWP project in December 2017. ${ }^{2}$ In addition, secondary data such as policy documents, press releases, journal papers, and project webpages support the analysis. ${ }^{3}$

The analysis is structured according to two types of interactive learning spaces. One is a project management interactive learning space related to the project development and construction stages of the wind parks. The other is an interactive learning space related to the operations and maintenance phases of the projects. In each case we:

1. Introduce the specific context and institutional settings of the megaprojects, including identifying the key actors - who is interacting with whom.

2. Analyse how a proactive strategy of creating an interactive learning space can spur capability-building in project management as an example of local high-skilled capability-building. 
3. Analyse how a proactive strategy of creating an interactive learning space can spur capability-building within operating and maintenance of the wind turbines as an example of local medium to high-skilled capability-building.

In the following, first the Adama case and then the Lake Turkana Wind Power case is presented. The main learning from the two cases is discussed followed by a conclusion.

\section{The Adama II wind power case}

\section{Key actors in the Adama wind power project}

The Adama wind power project, Adama I and II, in Ethiopia is owned by the state-owned electricity producer Ethiopian Electric Power (EEP). It is a joint venture between the Chinese turnkey contractor HydroChina and the CGCOC group, a Chinese construction company. Phase I was finalised in 2012 and added $51 \mathrm{MW}$ to the electricity grid. Phase II was commissioned in 2015 adding an additional $153 \mathrm{MW}$ to the grid.

The total investments of US $\$ 462$ million (US $\$ 117$ million in phase I and US\$ 345 million in phase II) of the projects were financed by preferential export buyer's credit from the China Exim bank $(85 \%)^{4}$ and own capital of EEP and the Government of Ethiopia (15\%). ${ }^{5}$ The financing agreements specified that Chinese wind turbine generator (WTG) technology was to be used. For Adama I, a Goldwind direct drive model (GW77/1500) was used while Adama II was completed with a gear box model from Sany (model SE7715). The following presentation of findings will focus specifically on interactive learning spaces occurring in Adama II's overall management of the construction phase and the succeeding maintenance phase.

As a turnkey contractor, HydroChina was responsible for the entire industry chain, from design and financing right through to engineering construction, equipment, and project contracting. They have multiple design and construction teams in China, and HydroChina's project manager for Adama II explained how they were able to work with the teams with the most experience required for this type of project (e.g., turbine model and construction requirements). The investment model, design, and blueprints from the project were proposed by HydroChina and CGCOC and negotiated with EEP. The final Engineering, Procurement, and Construction (EPC) contract included the design, manufacturing, supply, installation, testing, and commissioning of the project, including all ancillary works and civil works.

Following on the practice of the Ashegoda wind power project and Adama phase I, the Government of Ethiopia requested that Ethiopian universities submit proposals to act as owners' consultants on the project. For phase II, EEP hired a team of consultants from two Ethiopian universities (from Adama Science and Technology University (ASTU) and Mekelle University (MU)) as construction 
supervisors and contract administrators. According to the terms of reference, the aim of bringing in the university consultants was to:

- Build the capacity to implement construction contracts based on foreign technologies and suppliers,

- Build the capacity to manufacture main components such as towers and blades, and

- Eventually to build the capacity to manufacture and develop own technology.

At the peak construction period, HydroChina is estimated to have had over 200 employees working on site. The managing team was around 20-30 employees from HydroChina's head office, including subsidiaries. The construction teams were specialised in for example transmission lines, sub-stations, and turbine erection. Sub-contractors included Beijing Engineering Corporation Limited, 'Bureau no. 5', and SinoHydro - all under the HydroChina mother company. While all sub-contractors were Chinese, a large number of Ethiopians were employed during the project construction. The large number of Chinese employees during this phase reflects that the job types varied and that the project management (also based on the CVs of HydroChina's key personnel) was mainly carried out by Chinese employees. The key project management personnel counted approx. 13 Chinese staff for phase II, ten of which had already worked on phase I. Figure 8.1 illustrates the key actors involved in the Adama II project.

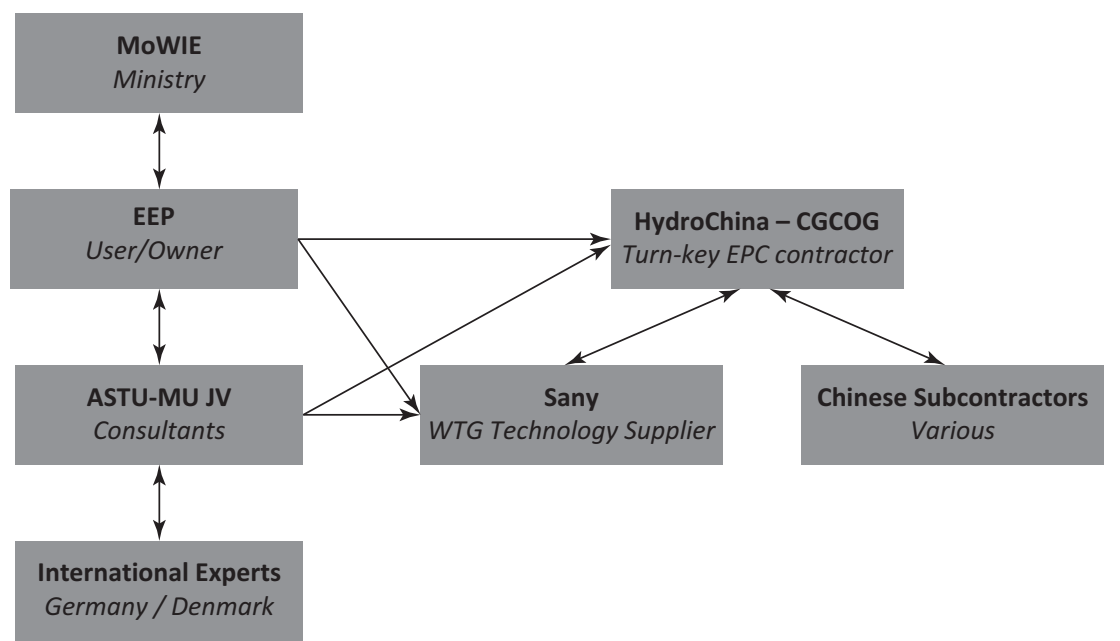

FIGURE 8.1 Key actors involved in Adama II project. Source: authors 


\section{Interactive learning spaces and capability- building in project management}

In Adama II the team of consultants from Adama Science and Technology University (ASTU) and Mekelle University (MU) signed a joint venture to engage in the consultancy contract. The consulting team was made up of 17 academics from the two universities, working as project managers, a resident engineer, and three teams of engineers: civil engineers (structural, geo-technics, and a surveyor); power/electrical engineers (SCADA, communication, control, machine); mechanical engineers (structure and aerodynamics); and one environmental expert. These three teams mirrored the set up on EEP's team, while HydroChina's teams included the design team, construction team, and the managing team.

The Chinese teams were brought in to complete their respective tasks during implementation for short periods of time, to save time. For some civil works, for example ditch construction, only a Chinese foreman was involved to instruct workers based on the overall planning and design. In terms of choice of employees, locals who were affected by the land use were offered employment first, e.g., in civil works or as guards. According to a project manager, HydroChina's salary was two to three times higher than an average salary would have been for these workers.

The university consultancy team's main tasks were to manage the overall supervision of the implementation of the project in contract administration and design verification, including:

- Optimised energy prognosis

- Approval of WTG selection

- Substantiation of micro-siting for turbine layouts

- Construction and erection supervision

- Acceptance testing start up, commissioning, and initial operation of the plant

- Handover of the project and preparation of project manuals, reports, etc.

As specified in the contract, the university consultants hired international experts, from companies such as the Danish wind turbine technology company, Norwin, and German rotor blade specialists, CP Maxx, who possessed the required knowledge in wind energy and wind turbine technologies. These international experts conducted training sessions with the university consultant team in their areas of expertise, including on issues regarding international standards, quality control, and inspection and reported on issues such as control of blades after transportation.

There were weekly meetings between the EEP manager, the consultants, and various teams from HydroChina. They would discuss progress made and plans for the following week. Sometimes deadlines were given for evaluations, negotiations about extensions on certain parts of the work, as well as negotiations about 
technical issues. There was a reporting mechanism to the Ministry of Water, Irrigation, and Electricity (MoWIE) and meetings with government officials, where every team head had to report their experiences. 'It's a kind of not only consulting, it was also an experience sharing, searching for us. Because it is a new project and the government is planning to expand it. So, a pool of experts was needed' (interview with university consultant, 11 November 2017).

The majority of university consultants came from technical backgrounds in thermal, industrial, and mechanical engineering, but they had not worked on wind energy projects before. The university consultants as well as EEP staff on the projects had received a number of training courses, including at the manufacturers' location in China, as well as on site. The desired skills transfer to the university consultants was specified as consultancy and project management skills. For EEP, the major skill to learn was how to control the contractor, e.g., what kind of reporting is most important, and what clauses should be included in the contracts in the future.

Bringing in university researchers as part of the knowledge transfer is specific for wind energy projects in Ethiopia and has not been done for example in the big hydro power projects. As mentioned, EEP has a duty to report to the Ministry (MoWIE) on the progress of the project and they pay particular attention to the issue of knowledge transfer:

We will focus on knowledge transfer and how that is happening. And we will ask the employees there, EEP employee, whether they acquired desired knowledge or not. In that case there was for example documentation issues. The documentation issue and I think they say they don't reveal some design document or something like that. So, we try to solve that kind of problem and also, we will see also with their quality of material is up to the standard or not. We will ask our EEP partners about the quality of their Chinese work.

(Interview with a ministry official, 13 November 2017)

However, challenges were outlined in the institutionalisation of such knowledge transfer, due to employee turnover from project to project:

I think the problem with knowledge transfer is that there is turnover of employee, that is the main problem. Like after they acquired some basic knowledge, there is a turnover of employees.

(Interview with a ministry official, 13 November 2017)

\section{Interactive learning spaces and capability- building related to maintenance}

Part of the Engineering, Procurement, and Construction (EPC) contract specified that EEP staff were to receive training from HydroChina and Sany in 
order to hand over the maintenance and plant management tasks swiftly once operations started. There was a relatively short handover period from Sany (as technology suppliers in phase II) and HydroChina with only an Operation and Management $(\mathrm{O} \& \mathrm{M})$ support agreement rather than the standard practice in the industry with a service agreement of five years or more. The required training in operations and maintenance will however have increased the skills transfer.

HydroChina had a team on site for three years for training purposes, particularly for EEP's engineers to train them on sub-station management, for example adjustment of power. Furthermore, a team from Sany was on site during the warranty period of the nacelles and to hand over and conduct continuous training in maintenance.

The training began already in the construction phase where EEP engineers and university consultants were invited to China for one month of training. According to interviewees, between 20-30 persons (engineers and supervisors) attended this training. The planned activities included factory visits, power plant visits, and classroom teaching. Once operations began there was a fourmonth training on site at Adama II. Two dedicated trainers from HydroChina remained on site after installation to conduct these trainings, one focused on WTG training and one focused on sub-station management. This training included classroom teaching as well as on-the-job training. The overall handover from HydroChina to EEP staff entailed the sharing of manuals and technical drawings of the WTGs and sub-station design, basic knowledge of how to run the WTG and the plant, standard processes for troubleshooting and reparations, as well as how to manage a maintenance team. As an interviewee recounted, the troubleshooting process aims to tell engineers to 'follow this ticket' next time so the engineers have 'no need to think by themselves' (interview with a project manager, 9 November 2017). A challenge highlighted by HydroChina was how to create training programmes when levels of education varied to a much greater extent than expected or when it was unclear whether the counterparts were certified engineers or interns not yet finished with their education. In fact, HydroChina's project manager recounted how company training in HydroChina China is a long-term and continuous process including job rotation schemes, monthly examinations, and mandatory courses before promotions and operation codes exist for every employee on a power plant. Transferring such a plant management scheme from one organisation to another may be very challenging and the interviewees raised some challenges in the transfer of skills listing; e.g., differences in work culture between Chinese and Ethiopian engineers as a major hurdle, the level of acceptance of the Chinese ' $24 / 7$ ' work culture, as well as inevitable lost in translation issues (interview with a project manager, 9 November 2017). It was reported, however, that one of HydroChina's long-term plans is to open a training centre in Addis Ababa. 


\section{Summary}

Overall, the case of Adama II illustrates how the Government of Ethiopia specifically created and institutionalised an interactive learning space by bringing in the university consultants. The aims of technology transfer were clearly outlined, and distinctive types of interaction arose between multiple actors in the project management of construction. As indicated in Figure 8.1, interactions were manifold between all key actors. During the operations and maintenance phase, a different type of interactive learning space occurred as defined by the support agreement between HydroChina, Sany, and EEP. This learning space was defined by standardised learning opportunities related to handover of WTG operations and sub-station management including classroom teaching and onthe-job training for EEP engineers.

Despite the efforts to be proactive and design these interactive learning spaces, several challenges arose in the interactions and the subsequent transfer and use of the knowledge generated by the consultants involved in the projects. New teams were formed for each wind project without handover from the previous project other than EEP's own project reports. In addition, HydroChina and Sany, the project developers, were responsible for the design, installation, and construction from beginning to end, with different units from headquarters fulfilling each task. Local staff was hired for some construction jobs but otherwise the staff was largely Chinese. Some of the challenges mentioned for the actual knowledge transfer include:

- Communication difficulties, including the use of translation during the training courses.

- Problems in relation to sharing documentation from the manufacturer and labelling in Chinese rather than English.

- High turnover of EEP staff - one of the reasons for continued training courses for new employees.

Further, a number of sources of conflict strained the relations between suppliers and users and the consultants as intermediaries, including; disputes over the verification of parts of turbines delivered being new or used, e.g., the installation of old generators on the project painted to look new, and general suspicion of the quality of Chinese products and unplanned changes for cost reduction. The university consultants recounted that while Chinese project managers maintained that things were done to plan, local staff shared different information regarding how the project was progressing. Similar challenges occurred when discussing whether manufactured goods and design of the sub-station followed international or Chinese standards; Sany's production in China follows the Chinese national standards for the industry which was according to the equipment contract. 


\section{The Lake Turkana Wind Power case \\ Key actors in the LTWP wind power project}

The LTWP project in Kenya was the largest wind power project in Africa with its 310-MW installed capacity upon commissioning in 2019. The total costs of the project reached EUR 678 million and covered the installation of 365 wind turbines in a remote area in the Marsabit region in Northern Kenya. The project furthermore entailed the construction of more than $428 \mathrm{~km}$ new transmission line as well as the upgrading of over $200 \mathrm{~km}$ of roads and various bridges. The project is operated as an independent power producer (IPP) owned by the LTWP consortium.

The project owners hired an international engineering consulting company, Worley Parsons, for the engineering, design, and construction management (EPCM) contract. In essence, this contract was an overall project management contract to ensure 'interfacing, i.e., managing budgets and avoiding delays between work sub-contracted out to different suppliers. This is a typical kind of organisational arrangement in megaprojects where turnkey contractors are difficult to find (Steen, Ford, and Verreyne, 2017). As indicated in Figure 8.2, in the LTWP case, the project was divided into five main contractors: Vestas (wind turbine generators), Siemens (grid and sub-station), RXPE (Statcom - Static synchronous compensator), SECO (camp construction), and CIVICON (road construction). Worley Parsons acted as LTWP's 'eyes and ears' on site, ensuring the smooth collaboration between the five major contractors engaged for the construction phase. Each contractor hired sub-contractors to complete parts of their work, and local Kenyan firms were engaged by e.g., Siemens for part of the electrical cabling works. Other sub-contractors for e.g., Vestas included regional firm EGMF for work on the foundations and Bollore Logistics for the specialised

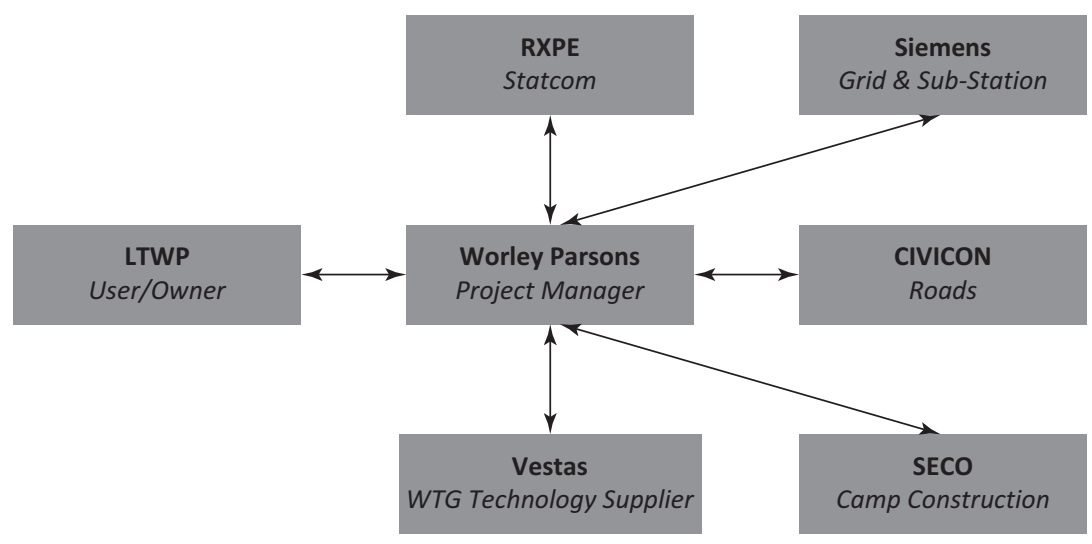

FIGURE 8.2 Key actors involved in LTWP project. Source: authors 
transportation from Mombasa Port to the site. However, while Worley Parsons acted as project managers during the construction phase, in the many years leading up to the financial close of the project, the LTWP consortium and 'founding fathers' ${ }^{\prime 6}$ of the project planned and designed the project in great detail. Thus, the choice of technology supplier, simulations of grid stability for a 310-MW wind power plant as well as road construction dilemmas and a number of other problem-solving activities were carried out by the owners.

\section{Interactive learning spaces and capability- building in project management}

Speaking to the project managers of the LTWP the project appears as very mission driven; they strived to complete an unparalleled project in a very challenging geographical location in order to prove to the world that such a project is possible. The project was developed as an Independent Power Project (IPP), and as the first major wind power project in Kenya it required new knowledge and skills for both project developers and regulators. The project developers faced and overcame a range of challenges from working with local communities (obtaining and maintaining their social licence to operate), negotiating the first Power Purchase Agreement (PPA) for wind in Kenya, to facing delays in externally managed critical parts for project commissioning (the transmission line) and subsequent critiques. The LTWP special purpose vehicle was established in 2006 to develop the feasibility studies, planning, and negotiations for the project which ran until financial agreement was reached in 2014, a period of eight years. Over this time and in response to multiple critiques the project was designed to specifically reflect commitment to involving the local communities both through employment plans and corporate social responsibility (CSR) activities. For example, contractors, such as Vestas with a long-term involvement, were asked to include training programmes.

It was a requirement of LTWP to have some form of training, we couldn't tell them what to train them in, but had to say, you are here for 15 years doing O\&M, so you are one of the companies that is here long term, we need to see you do some training, so they selected what they wanted. We didn't say you will do it on turbine maintenance but it's the obvious.

(Interview with LTWP manager, 5 December 2017)

Despite the focus on CSR and community engagement, the project management approach described by interviewees was focused on interface management: identifying the critical paths of all the contracts, how they interlink and where risk of delays would be critical for the completion of the project. As indicated in Figure 8.2 , this created a hierarchical design of interactions. However, within this structure 
there was a focus on intra-organisational learning through community recruitment. Sub-contractors were mandated to follow LTWP's aims of engaging local communities and prioritising job opportunities for the communities in the concession area before engaging Kenyan nationals from other regions of the country. While this was not guided by governmental requirements on for example local content, it was an approach that was constructed by LTWP in collaboration with key local actors as a strategy for 'earning and retaining' a social licence to operate. At peak construction, approximately 1,700 people were employed, the majority of whom were local (LTWP, 2017). Beyond the construction project management by Worley Parsons, LTWP can be identified as the key actor and repository of knowledge for capabilities on wind power project management. The 'founding fathers' accumulated the necessary knowledge through different activities of problem solving and searching as a result of their interaction with many different actors in the value chain of the project. According to one of the LTWP managers, none of the original team had previous experience in the wind industry. They simply had to learn on the job and bring in expertise:

we just hit the ground running and said that this is what we are going to do and who can do what. We all decided and then we all went off and did our own bits and then we met once a month. We'd come back here from the field, sit, talk, this is what we have got to do and then we disappear again and come back again and meet the next month and just that's how we just got the ball running to start with.

(Interview with LTWP manager, 5 December 2017)

LTWP's interactions with upstream and downstream actors proved an excellent channel for interactive learning for LTWP as an organisation. LTWP could be seen as an intermediator attaining the ability to translate codified analytical and engineering knowledge of suppliers in the wind industry to their downstream partners (Kenya Power and Lighting Company, the Ministry of Energy and Petroleum, the Energy Regulatory Commission, the Kenya Transmission Company).

Everybody involved had a huge learning curve because we employed or hired the cream of the crop across the globe on grid stability. KEMA for example, which is a Dutch company - we actually got them to do a study on the national grid system to see if it could cope with the power and they gave that report to the government so they had to base plate to grow on and work on. And now KEMA is actually continuing to consult for them to make sure the grid works for all the other projects that are coming online. It's been great for Kenya. It's a fantastic project and so many people have learned so much.

(Interview with LTWP manager, 5 December 2017) 
During the planning and development phase (2006-2014), LTWP as an organisation accumulated experience by interacting with a very heterogeneous group of stakeholders, from the local authorities who had little experience in the type of negotiations for such a large scale wind energy project, to contacting suppliers upstream in the value chain and convincing them of the business case. Furthermore, LTWP hired a large number of local unskilled labourers around the site for manual labour and site preparations. International expertise was brought in by hiring consultants and specialists to advise on the planning of the project, e.g., the experts from KEMA who made simulations of the grid integration. Both LTWP as well as local authorities were able to use this as a learning experience and implemented their experiences when bringing the project forward (Gregersen, 2020).

\section{Interactive learning spaces and capability- building related to maintenance}

As mentioned above, the Danish wind turbine producer Vestas was contracted to supply and install 365 WTGs during the construction phase as well as to manage the operations and service of the WTG for a 15-year period once the project was commissioned. As an industry leader, the knowledge required to perform these tasks already exists within the organisation. However, formation of an interactive learning space can be identified in the process of recruiting and training a team of engineers that will work on the service contract for the first 15 years of this.

Vestas' philosophy is to have an interim phase between installation and operations, with an overlap between the two teams taking care of each of these phases. Part of the service team was therefore recruited before the full operations started, in order to ensure association with the construction and to assist during the construction. This strategy aims to ensure a smooth transition from the construction to the operations phase.

LTWP followed a recruitment policy that favoured the recruitment of as many workers as possible from the communities in the immediate geographical constituency of the project. This was translated into contractual agreements for all contractors and sub-contractors including a target of $20 \%$ of the total employment being from the communities in the region. Vestas set additional targets, to recruit up to $95 \%$ of their employees from the Northern Kenyan region (interview, 4 February 2019).

The service team was recruited in teams of six. The first two teams recruited Kenyan technicians and diploma engineers with backgrounds in mechanical engineering, electronic communication skills, and higher level of experience (eight to ten years) within heavy engineering industries (e.g., with generators or in oil fields) (interview with service team manager, 4 February 2019). For the third and fourth teams there was a focus on hiring as many new university graduates from the immediate region as possible. In both teams, four or five of the selected technicians were from the communities living within and surrounding 
the project concession while the final recruitments for each team were made at the national level.

So, these are the guys right now, the guys that you see walking around here in blue and black with Vestas on their back. They are all local, be it local local or from up country, who are currently maintaining the turbines so they have all had training already. [...] they were taken off to Denmark and [received] training on how to maintain this specific type of turbine. So, it is basically gearbox maintenance, checking oil, dust leaks, oil leaks, bearings of the nose cone of the turbines, the electrical to a degree.

(Interview with an LTWP manager,

5 December 2017)

Vestas technicians worldwide are required to undergo a standard global wind $(\mathrm{GW})$ organisation training. Furthermore, Vestas has developed programmes for vocational and theoretical coaching and has a simulator on site at LTWP to train the service team in troubleshooting and maintenance of the turbines. Thereafter, ex-post training takes place on the job, both through a buddy programme pairing junior technicians with senior colleagues and by bringing in experienced service technicians from other Vestas departments. In the case of LTWP, technicians from Greece and South Africa were brought in to support the service team at the upstart of operations.

An on-site GW training kit on safety practices and 'train the trainer' programmes enable service team supervisors to undertake training for new recruits. Additional training needs based on skills and certification levels are available at Vestas' global training facilities. The key actors in the learning space that was created to train the Vestas service team are thus all within the global organisation Vestas, including the service team itself, the training facilities in Germany and Denmark, as well as the experienced service technicians who were brought in from other departments.

\section{Summary}

The project management interactive learning space in the LTWP project is characterised by its mission driven and problem-solving approach. While Figure 8.2 illustrates a more hierarchical type of interaction this is limited to the construction management phase of the project. In fact, the interactive learning space for project management originated with the 'founding fathers' of the project who took on the role as the key actor and repository of knowledge. For construction management, project management was then outsourced to Worley Parsons and interactions among sub-contractors was limited to issues of interfacing and time management. The project management interactive learning space is therefore more broadly viewed as spanning from the project's conception and managing its development on a more holistic level, while project management of the 
construction period in itself was a different space where more limited learning may have been shared between actors. The LTWP interactive learning space on project management is not characterised by a proactive strategy on behalf of the government of Kenya. ${ }^{7}$ Rather it is embedded in the existing energy system where IPPs are encouraged and therefore LTWP themselves had to create a space in which they could learn how to manage an IPP. Within this space they acquired the necessary knowledge about issues ranging from conducting feasibility studies for the site, road surveys, and grid simulations to what clauses to include in a power purchase agreement for wind power plants.

The maintenance learning space in the LTWP project is bounded by the organisational borders of Vestas (Gregersen, 2020). Because of the 15-year service contract the learning space is highly intra-organisational as Vestas needs to recruit and train a team of engineers to fulfil this contractual task. Although the team is project based, it is a long-term investment to train the employees which is backed up by the highly standardised educational programmes of the company, including the GW trainings, simulations, and on-the-job training.

Interesting questions arise as to whether the experience-based learning in the LTWP case results in 'local' knowledge, especially as the learning space in the maintenance phase is defined as exclusive to Vestas employees. Furthermore, the learnings accumulated by the LTWP developers is bounded by the project-based nature of the power plant and the uniqueness of the project. The prospective wind power plans in Kenya have been limited to projects that are much smaller in size and there are no concrete plans for LTWP to develop and own more wind projects at the time of writing.

\section{Learning from the two cases}

Looking across the two cases there are interesting similarities and differences concerning where and under what institutional setting the two large wind power projects have created local interactive learning spaces with opportunities for skills upgrading and local capability-building. In large complex infrastructure projects like Adama II and LTWP, multiple organisations and complex interactions are involved, and in principle all actors may gain experience and obtain new or adjusted knowledge that may be accumulated and used within the project as it develops and/or is transferred to another context. While such learning by doing, using, and interacting is key as it emerges and takes place everywhere all the time during a concrete project, it also raises an important question, as to whether learning spaces can be deliberately designed to support skills upgrading and local capability-building in the long run. Based on the analysis earlier in this chapter, two parallel examples in each of the two wind farm projects were selected to serve as illustrations of such deliberately designed learning spaces. One learning space is connected to managing the process and the other to maintenance. The different phases have different involvement of actors, activities, key technologies, and requirements of knowledge domains. While other studies have introduced 
the concept of project capabilities, referring to important activities of bid preparation and project execution (Davies and Brady, 2000), this chapter shows that it is useful to make even further distinctions in the organisational learning cycle of wind power projects.

Table 8.1 summarises the main characteristics of the four selected interactive learning spaces.

The Adama II and LTWP cases have raised interesting questions regarding the promotion of learning within and across organisations. Jensen et al. (2007) argue that firms can promote the doing, using, and interacting mode of learning

TABLE 8.1 Main characteristics of selected learning spaces

\begin{tabular}{|c|c|c|}
\hline $\begin{array}{l}\text { Management } \\
\text { learning space }\end{array}$ & Adama & LTWP \\
\hline $\begin{array}{l}\text { Context and } \\
\text { institutional } \\
\text { setting }\end{array}$ & $\begin{array}{l}\text { EEP-owned power project designed, } \\
\text { constructed, and handed over by } \\
\text { Hydro-China-CGCOC }\end{array}$ & $\begin{array}{l}\text { Independent power } \\
\text { project developed, } \\
\text { designed, and } \\
\text { operated by LTWP }\end{array}$ \\
\hline Key actors & $\begin{array}{ll}\text { - } & \text { EEP } \\
\text { - HydroChina-CGCOC } \\
\text { - }\end{array}$ & $\begin{array}{l}\text { - } \text { LTWP } \\
\text { • Kenyan authorities }\end{array}$ \\
\hline $\begin{array}{l}\text { Capabilities in focus } \\
\text { (direct/indirect } \\
\text { skills) }\end{array}$ & $\begin{array}{l}\text { To manage and implement } \\
\text { construction contracts }\end{array}$ & $\begin{array}{l}\text { To manage } \\
\text { and implement } \\
\text { construction } \\
\text { contracts }\end{array}$ \\
\hline $\begin{array}{l}\text { Reactive or } \\
\text { proactive by } \\
\text { design }\end{array}$ & $\begin{array}{l}\text { Designed by GoE to involve } \\
\text { universities in the contract } \\
\text { management and supervision }\end{array}$ & $\begin{array}{l}\text { Emerging with } \\
\text { elements designed by } \\
\text { financial stakeholders } \\
\text { to involve training of } \\
\text { local workforce }\end{array}$ \\
\hline $\begin{array}{r}\text { Inclusive or } \\
\text { exclusive }\end{array}$ & - Inclusive & - Inclusive \\
\hline $\begin{array}{l}\text { Maintenance } \\
\text { learning space }\end{array}$ & Adama & LTWP \\
\hline $\begin{array}{l}\text { Context and } \\
\text { institutional } \\
\text { setting }\end{array}$ & - Short term handover contract & $\begin{array}{l}\text { - } 15 \text {-year service } \\
\text { contract }\end{array}$ \\
\hline Key actors & $\begin{array}{l}\text { - Sany } \\
\text { - EEP }\end{array}$ & - Vestas \\
\hline $\begin{array}{l}\text { Capabilities in focus } \\
\text { (direct/indirect } \\
\text { skills) }\end{array}$ & $\begin{array}{l}\text { - Operations and maintenance of the } \\
\text { WTG and plant management }\end{array}$ & $\begin{array}{l}\text { - Operations and } \\
\text { maintenance of the } \\
\text { WTG }\end{array}$ \\
\hline $\begin{array}{l}\text { Reactive or } \\
\text { proactive by } \\
\text { design }\end{array}$ & - Designed by HydroChina/Sany & - Designed by Vestas \\
\hline $\begin{array}{r}\text { Inclusive or } \\
\text { exclusive }\end{array}$ & - Exclusive & - Exclusive \\
\hline
\end{tabular}


by building structures and relationships which enhance and utilise learning by doing, using, and interacting (e.g., project teams, problem-solving groups, and job and task rotation, all of which promote learning and knowledge exchange). Project-based construction is thus necessarily interactive and problem solving. However, the two wind power project cases show important differences in the way interactive learning spaces can be designed and shaped to proactively contribute to a desired future. The case of Adama II has an interesting institutional setting supporting high skilled knowledge transfer. From the very beginning, Ethiopian universities became involved on a contractual basis with the explicit aims to secure knowledge transfer and local capability-building on wind technologies. The LTWP project did not have a similar involvement of universities or other national public knowledge institutions. Instead, skills upgrading and capability-building were regulated by contractual agreements between LTWP and a number of different sub-contractors. To secure that knowledge transfer and experience-based learning become locally rooted may be more difficult under this institutional construction.

In both the Adama II and LTWP cases the learning spaces for maintenance are characterised by efforts to codify knowledge through manuals and tailored training programmes. However, the need for other modes of learning is shown in the complementarity of on-the-job training programmes and 'buddy' systems, that foster informal communication and sharing. This mobilises the tacit knowledge of senior technicians as well. Empirical work has shown that both tacit and codified modes of learning and innovation play a role and in fact the combination may promote more innovation than either or (Jensen et al., 2007).

Johnson and Andersen (2012) point to the importance of inclusivity of learning. On a general level, inclusion refers to broad and active participation in a process of change. The project management learning spaces may possibly be viewed as more open and diverse in terms of the actors involved. Other empirical studies have proposed that the type of relational activities of project management include capability-building exercises, as the process itself becomes a learning experience as the team gradually develops its resource base (Söderlund, Vaagaasar, and Andersen, 2008; Hanlin and Okemwa, 2022; this volume). The case of Adama was explicitly designed to include universities (staff and students) while LTWP engaged many different stakeholders in a problem-solving process driven by the developer's interest. The maintenance learning spaces were more exclusively operated between trainers and engineers with a hierarchical structure. In the case of Adama this involved an inter-organisational transfer of knowledge while in LTWP this consisted of the accumulation of capabilities by a team within the organisation. The cases of learning spaces in maintenance highlight that despite their exclusivity, they are in fact spaces in which experience and knowledge can be applied in a formalised and tested learning culture.

Inclusion of universities as a proactive strategy is a way to ensure that knowledge and experience is shared in a key renewable electrification effort. However, while the inclusion was formalised in terms of a contract and specific tasks being 
outlined, it is also important to pay attention to the quality of the interactions and linkages. Particularly, problems of trust between actors can arise when the vision or mission has not been created together. For example, the university consultants in Adama expressed feelings of not being able to change anything that was already agreed or designed between HydroChina and EEP. Their mandate limited their role beyond objecting and waiting for rectifications during the construction phase. Johnson and Andersen (2012) do note that interactive learning spaces give rise to learning linkages mostly within the boundaries of the interactive space itself. As a consequence, reflections about inclusivity/exclusivity is important through all phases of such projects. Circling back to the mission setting of an interactive learning space one could question what opportunities exist for learning in exclusive learning spaces to be used beyond the learning spaces boundaries. For example, what opportunities do the service engineers of Vestas have to use their new knowledge beyond maintenance of the WTGs in Lake Turkana? Does any discussion of their experience feed back to Vestas' headquarters and training facilities? What opportunities do the university consultants have to use their acquired skills in project and contract management? How realistic are the efforts taken to ensure technology transfer for the longer term aims of component manufacturing in Ethiopia? Should one learning space be followed by another once it has been 'shut' (for example after the end of the contractual obligations binding HydroChina, EEP, and the university consultants' interactions)? These questions relate to discussion on the importance of avoiding 'de-learning', i.e., when interactive learning spaces are shut down or disappear (Arocena and Sutz, 2000).

\section{Conclusion}

In this chapter we showed that by a deliberate creation of interactive learning spaces it is possible to establish and further develop local high-skilled jobs in relation to large turnkey infrastructure projects when key technologies are imported.

The two large wind power projects (Adama II and LTWP) formed the point of departure to examine and engage with the concept of interactive learning spaces in global collaborative efforts towards renewable electrification. Interactive learning spaces have provided a way to understand micro-level interactions between different group of actors in specific contexts. In particular, the way in which future infrastructure projects are conceived in policy, as well as designed, developed, and implemented in practice. Issues of directionality, distribution, and diversity of learning spaces need to be raised and considered - is a learning space designed to be inclusive or exclusive? What efforts can be made to identify, foster, and protect interactive learning spaces? The ways to do this are manifold, depending on the problems and the actors around which the learning places are constituted within renewable electrification efforts at large. In particular, thinking of such wind power projects as opportunities to search for and apply 
knowledge is part of creating systemic learning from project to project. This has implications for policy making for a learning-based industrialisation, where focus is rather on collective capabilities and job creation, rather than catering only to those engaged in the individual projects.

The overall argument here is that opportunities to learn must be open and kept open and not only rely on temporary and fleeting learning spaces bounded to investment projects where key technologies and expertise are 'flown in' from abroad. The long-term role and linkages of these projects with local actors in the systems must be put in focus (Lema et al., 2018). However, this requires deliberate policy decisions and actions to make sure that skills upgrading and capabilitybuilding are institutionalised and grounded in local organisations. As the Adama II and LTWP cases show, this can be done in different ways.

\section{Acknowledgements}

This research was supported by the Danish Ministry of Foreign Affairs grant DFC 14-09AAU. The authors are very grateful for the constructive comments and ideas of the editors.

\section{Notes}

1 See Andersen and Lema (this volume) for a broader discussion of three key elements in the renewable electrification process: learning, development of capabilities, and the resulting outcomes.

2 A total of 37 semi-structured interviews with key actors were conducted between February 2017 and February 2019 focusing on the employees' roles, relationships with project members, and practices of collaboration, coordination, and interaction.

3 A more detailed analysis of the relations and interactions of the LTWP case study can be found in Gregersen (2020), while the Adama case study is also featured in Lema et al. (2021). The findings presented in this chapter draw upon the analysis of these studies but views and discusses them through the lens of interactive learning spaces.

4 At an interest rate of $2 \%$.

5 The investment estimation did not include permanent and temporary land compensation expenses.

6 The project was developed by a group of Dutch, Kenyan and Norwegian entrepreneurs who have been labelled as the 'founding fathers' of the project. They worked together with Dutch-registered KP\&P, a company with history of developing and operating wind power projects.

7 At the time of LTWP's development there were no local content regulations beyond the oil and gas sector in Kenya, however, the 2019 Energy Act has emphasised the need to develop local capabilities to manufacture, install and maintain renewable energy and stipulates that firms are expected to submit local content plans, including the use of Kenyan contractors and staff were qualified and available (Hanlin, Okemwa and Gregersen, 2019).

\section{References}

Arocena, R. and Sutz, J. (2000) 'Interactive learning spaces and development policies in Latin America', DRUID Working Paper No. 00-13. https://wp.druid.dk/wp /20000013.pdf (Accessed: 06/02/2020). 
Bell, M. (2007) 'Technological learning and the development of production and innovative capacities in the industry and infrastructure sectors of the least developed countries: What roles for ODA?', Background Paper for the UNCTAD Least Developed Countries Report 2007. https://unctad.org/Sections/ldc_dir/docs/ldcr2007_Bell_en .pdf (Accessed: 06/02/2020).

Bell, M. (2012) 'International technology transfer, innovation capabilities and sustainable directions of development' in Ockwell, D. and Mallett, A. (eds.) Low Carbon Innovation and Technology Transfer. Low Carbon Development: Key Issues, pp. 109-128. London and New York: Routledge. DOI:10.4324/9780203121481

Cohen, W.M. and Levinthal, D.A. (1990) 'Absorptive capacity: A new perspective on learning and innovation', Administrative Science Quarterly, 35, pp. 128-152. DOI:10.2307/2393553

Davies, A. and Brady, T. (2000) 'Organisational capabilities and learning in complex product systems: Towards repeatable solutions', Research Policy, 29(7-8), pp. 931-953. DOI: 10.1016/S0048-7333(00)00113-X

Davies, A. and Hobday, M. (2005) The Business of Projects: Managing Innovation in Complex Products and Systems. Cambridge: Cambridge University Press. DOI:10.1017/ CBO9780511493294

Gregersen, C. (2020) 'Local learning and capability building through technology transfer: Experiences from the Lake Turkana Wind Power Project in Kenya', Innovation and Development, pp. 1-22. DOI: 10.1080/2157930X.2020.1858612.

Hanlin, R., Okemwa, J. and Gregersen, C. (2019) 'Building competences and capabilities through projects: Examples from Kenya's renewable energy sector', IREK Working Paper. Available at: http://irekproject.net (Accessed: 06/02/2020).

Hanlin, R. and Okemwa, J. (2022) 'Interactive learning and capability-building in critical projects', in Building Innovation Capabilities for Sustainable Industrialisation: Renewable Electrification in Developing Economies. New York: Routledge. https://doi .org/10.4324/9781003054665-7

Jensen, M.B., Johnson, B., Lorenz, E. and Lundvall, B.Å. (2007) 'Forms of knowledge and modes of innovation', Research Policy, 36(5), pp. 680-693. DOI:10.1016/j. respol.2007.01.006

Johnson, B. and Andersen, A.D. (2012) Learning, Innovation and Inclusive Development: New Perspectives on Economic Development Strategy and Development Aid. Globelics Thematic Report, 2011/2012. Aalborg: Aalborg Universitetsforlag. https://www.globelics.org/ publications/globelics-thematic-review/ (Accessed: 06/02/2020).

Johnson, B. and Lundvall, B.Å. (1994) 'The learning economy', Journal of Industry Studies, 1(2), pp. 23-42. DOI: 10.1080/13662719400000002

Lema, R., Bhamidipati, P. L., Gregersen, C., Hansen, U. E., and Kirchherr, J. (2021) 'China's investments in renewable energy in Africa: Creating co-benefits or just cashing-in?', World Development, 141(105365), pp. 1-18, https://doi.org/10.1016/j .worlddev.2020.105365

Lema, R., Iizuka, M. and Walz, R. (2015) 'Introduction to low-carbon innovation and development: Insights and future challenges for research', Innovation and Development, 5(2), pp. 173-187. DOI:10.1080/2157930X.2015.1065096

Lema, R., Hanlin, R., Hansen, U.E., and Nzila, C. (2018) 'Renewable electrification and local capability formation: Linkages and interactive learning', Energy Policy, 117, pp. 326-339. DOI:10.1016/j.enpol.2018.02.011

LTWP (2017) 'LTWP's construction labour summary report. August 2017'. Available at: https://ltwp.co.ke/newsite/wp-content/uploads/20170912-LTWP-Construction -Labour-Summary-Report-FINAL.pdf (Accessed: 06/02/2020). 
Lundin, R.A. and Midler, C. (eds.) (2012) Projects as Arenas for Renewal and Learning Processes. New York: Springer Science \& Business Media. DOI:10.1007/978-1-4615-5691-6

Petersen, I.H., Kruss, G., Gastrow, M. and Nalitava, P.A. (2018) 'Innovation Capacitybuilding and inclusive development in informal settings: A comparative analysis of two interactive learning spaces in South Africa and Malawi', Journal of International Development, 30(5), pp. 865-885. DOI:10.1002/jid.3232

Rennkamp, B. and Boyd, A. (2015) 'Technological capability and transfer for achieving South Africa's development goals', Climate Policy, 15(1), pp. 12-29. DOI: 10.1080/14693062.2013.831299

Söderlund, J., Vaagaasar, A.L. and Andersen, E.S. (2008) 'Relating, reflecting and routinizing: Developing project competence in cooperation with others', International Journal of Project Management, 26(5), pp. 517-526. DOI:10.1016/j.ijproman.2008.06.002

Steen, J., Ford, J.A. and Verreynne, M.L. (2017) 'Symbols, sublimes, solutions, and problems: A garbage can model of megaprojects', Project Management Journal, 48(6), pp. 117-131. DOI:10.1177/875697281704800609 